\title{
50 AÑOS EN PRIMERA VOZ
}

\section{YEARS IN FIRST PERSON}

\author{
Laura Viuda de Soria \\ Sergio Macías \\ Ximena Ortúzar \\ Jaime Lorca Tobar \\ Carlos Humberto Caszely \\ Vicent Garcés \\ Eulogio Dávalos
}

PALABRAS CLAVE: CHILE * TESTIMONIO * CAMBIO SOCIAL * POLÍTICA

KEYWORDS: CHILE * TESTIMONY * SOCIAL CHANGE * POLITICS

Quienes participaron en el programa de gobierno o compartieron los ideales de la Unidad Popular en Chile, vivieron un cambio en sus vidas que los marcó para siempre. Medio siglo después, actores desde diferentes disciplinas y áreas del saber, relatan cómo recuerdan aquellos días y las transformaciones que ha sufrido el país, desde ese entonces.

Desde la victoria de Salvador Allende a las reivindicaciones del estallido social de octubre que comenzó en octubre del año pasado, poetas, políticos, médicos, jugadores de fútbol, sociólogos y analistas revisan sus testimonios y rescatan similitudes $y$ diferencias.

Carolina Espinoza Cartes Marcos Roitman Rosenmann

LAURA VIUDA DE SORIA

MÉDICA EN LA UNIDAD POPULAR Y ACTIVISTA

-¿Qué significó para usted el triunfo de Allende?

Yo acompañaba a mi madre, María Marchant, en el local en el que ella trabajaba en la candidatura de Allende en 1952, ocasionalmente lo veía de lejos y por lo que me contaba mi madre, iba conociendo su programa. Y los rasgos de carácter de Allende, y en ocasiones, le venía trabajando con la gente. En 1958 estaba yo en la Escuela de Medicina y trabajaba junto a compañeros en el proyecto de salud allendista. Desfilábamos con batas blancas, con carteles que decían "medicina con Allende". En 1970, triunfó la UP, yo participaba como vocal en una mesa en Las Condes. Recuerdo que por la tarde se acercó a esa mesa Eric Schnake, diputado socialista y me dijo muy bajito, "vamos ganando", pero tú no sabes nada. Me fui caminando a la casa y había 
un gran silencio en el barrio, cuando llegué a mi casa, faltaban las mesas de Quinta Normal. La derecha aseguraba que ganaría Alessandri, que las mujeres le darían el voto. Y en realidad fueron las mujeres menores de 30 años quienes le dieron el triunfo y que se vio reflejado en su gobierno.

\section{-¿Qué significó el fin abrupto de esa}

"revolución" con el golpe de estado de 1973?

El Golpe que dieron los militares en Chile con el apoyo de la derecha y la Democracia Cristiana y con apoyo de los EE.UU. En 1970 yo me encontraba en el hospital San Borja, y recuerdo a los militares en la calle, con pañuelos naranja. Tiraron dos bombas lacrimógenas a la sala de pre parto, lo que causó la muerte de una de las pacientes y tuvo que acelerar la atención de otras. Desde el patio del hospital, pudimos ver a los aviones y el bombardeo e incendio de La Moneda. Después llegó al hospital un cardiólogo que había estado allí y que nos dijo "Allende se suicidó". Los médicos que estamos atendiendo hicimos un acto, muchos lloraron, yo estaba indignada. Cuando un médico de derecha entró a la habitación donde estaba y me dijo "Nunca quise que pasara esto" yo le dije que Allende era un hombre digno.

Para mi el 11 de septiembre fue una gran tristeza, por todos los que estuvieron en La Moneda. Luego comencé a trabajar en la resistencia en un grupo de médicos que nos preocupábamos de saber quienes estaban detenidos y saber lo que necesitaban. Así hasta 1976, en que la dictadura asesinó a mi marido, Carmelo Soria, español, funcionario de Naciones Unidas $y$ declaré e inicié el juicio por su asesinato. Posteriormente me vi obligada a exiliarme en España donde percibí una gran solidaridad. Allende fue un gran presidente, desde que inició su carrera política como ministro de salud en 1938 del Frente Popular y luego como diputado y Senador. Nunca se desvió de sus ideas socialistas para trasformar Chile. Fue un gran educador político y siempre tuvo una gran fe en el pueblo chileno, que fue el primer país del mundo que llegó al socialismo por la vía pacífica.

- ¿Cómo vive el movimiento que se generó en Chile tras el estallido social? ¿Ve similitudes con el proceso de la UP?
Hay símiles $y$ diferencias. La primera diferencia es que no tiene dirección política ni un líder. La similitud, es que atraviesa todas las capas sociales. Otra similitud con la UP, radica en que como consecuencia del propio estallido, las comunas se han organizado en Cabildos en juntas de vecinos, $y$ también la presencia de la cultura y el arte en las manifestaciones. Se han unido artistas, científicos, pobladores, mineros, es un movimiento que ha unido al pueblo, como lo unió en la up. También, así como el voto de las mujeres menores de 30 años fue crucial en la elección de Salvador Allende, podría decir que el feminismo, ahora, $y$ la presencia de la mujer en este movimiento social tras el estallido, ha tenido una gran presencia e influencia, por ejemplo, el grupo "Las tesis" con su performance "El violador eres tú" y que ha dado la vuelta al mundo.

\section{SERGIO MACÍAS}

POETA, NARRADOR Y ENSAYISTA

- ¿Cómo vivió el inicio del proyecto de la Unidad Popular en Chile?

Como ciudadano y militante del Partido Socialista fue una de las ilusiones políticas más grandes que he tenido, junto a los que le dieron el triunfo en Chile, $y$ a los ciudadanos de Latinoamérica, porque vimos un nuevo camino de libertad $y$ de justicia social. Si actualmente impera una desigualdad inaceptable, en aquella época era gigantesca, con menos recursos de todo tipo, con menos modernidad y globalización. Esto fue una de los motivos de que se eligiera el gobierno de Allende. A los pobres se les marginaba, menospreciaba $y$, a veces, cristianamente se les trataba de pobrecitos ayudándolos con algo de ropa $y$ comida, que algunas señoras de la clase alta después del té-canasta iban a dejar a las poblaciones, haciendo luego publicidad de la caridad que realizaban. Con la Unidad Popular surgía una nueva etapa donde el ser humano era lo más importante $y$, por eso, la educación y el medio litro de leche fueron fundamentales.

Viví el inicio del proyecto político con la fe del inocente, sin darme cuenta de los Caínes 
que se ocultaban debajo de la capa militar que usaban Pinochet y sus secuaces. Me integré en la Cup -en el Comité de la unidad popularde mi trabajo, aparte de mi militancia en el núcleo de intelectuales con Alejandro Chelén, Walter Garib, Fernando Daza, etc.

- ¿Qué significó el fin abrupto de esa "revolución" con el golpe de estado de 11.09.73?

Significó la división del país por parte de las fuerzas armadas, de la banca, del poder económico apoyado por Estados Unidos, tal como puede leerse en los documentos que tenía archivados la Cía. No iban a permitir por ningún motivo un gobierno de izquierda elegido en las urnas. Y la patria sufrió la tortura, la prisión, con ciudadanos desaparecidos y exiliados. Yo mismo debí salir de Chile, autorizado por el partido, con mi mujer y cuatro niños. Sin embargo, no estoy conforme con muchos dirigentes que al retornar se integraron en el sistema, se arreglaron "los bigotes", y se olvidaron de muchos valores por los que luchábamos para rentabilizar sus cargos importantes $y$, además, fueron varios los que no dejaron paso a la nueva generación. Algunos se hicieron viejos imitando el sistema de vida que combatían. Por eso, la izquierda ha perdido mucho poder, $y$ los clasistas siguen vivitos y coleando.

-¿Hay algo del espíritu de la UP en este nuevo proceso que pretende terminar con las inequidades del modelo impuesto por la dictadura?

Creo que la injusticia social viene de mucho antes de la dictadura. De regímenes que convirtieron a los ciudadanos de Chile en peones $y$ patrones de fundo $y$ de la banca, apoyados por los hijos de papás que los ingresaban en las academias de las fuerzas armadas cuando no podían llegar a la universidad. La historia del movimiento obrero en Chile es muy interesante (es necesario leerlo) porque surgieron dirigentes que les abrieron los ojos a los trabajadores y, por ello, se llegó a elegir un gobierno popular y democrático como el de Allende. La dictadura impuso un sistema peor que el de los orígenes. Una forma de capitalismo impuesto por Milton Friedman y los Chicago Boys, que agudizó las diferencias sociales, el individualismo y la falta de solidaridad hasta la fecha.

Y esto, ha dado como resultado que, con algo del espíritu de la unidad popular, salte por los aires una política reaccionaria que los débiles no pueden soportar. Y si no se remedia, esto tiene para mucho más. Confío en la juventud que tiene ideales, ilusiones por un mundo mejor, ecológico, con menos contrastes económicos, con un estado de bienestar no excluyente y una educación eficiente. Creo que la nueva generación está en el camino de eliminar a los corruptos $y$ tener dirigentes honestos $y$ preparados para enfrentar un mundo innovador con grandes desafíos tecnológicos.

\section{XIMENA ORTÚZAR \\ PERIODISTA}

- ¿Cómo vivió el inicio del proyecto de la Unidad Popular en Chile?

El triunfo de Salvador Allende el 4 de septiembre de 1970 fue noticia mundial: era el primer presidente socialista del mundo elegido por vía electoral. Como estudiante de periodismo sentí que Chile sorprendía al mundo con la noticia publicada en las primeras planas de prácticamente todos los países. Como allendista sentí que una inmensa luz llenaba de esperanzas a mi país, a los más necesitados, a los luchadores que desde sus diferentes trincheras (sindicalistas, militantes de izquierda, intelectuales comprometidos con el cambio) habían hecho posible ese histórico triunfo.

Allende había anunciado "El 3 de diciembre el pueblo de Chile entrará conmigo al Palacio de la Moneda”. A partir de ese día se inició la epopeya de sentar las bases de una transición al socialismo en democracia, en la certeza de que el camino estaría lleno de escollos y de que la derecha no escatimaría ningún recurso destinado a hacerla fracasar.

Con la fuerza de la convicción y la mística de la esperanza, obreros, campesinos, profesionales, jóvenes y mujeres comprometieron su apoyo para lograr que el Programa de las 40 Medidas aprobadas por los partidos de la Unidad 
Popular, $y$ anunciado por Allende se hiciera llevaran a cabo.

La derecha, que nunca baja los brazos si de defender sus derechos se trata, encabezó la sedición que comenzó aún antes del triunfo de la Unidad Popular mediante una campaña del terror y que se agudizó el mismo día del triunfo de Salvador Allende: la derecha intentó primero que su triunfo no fuera legitimado por el Congreso; procuró convencer al comandante en jefe del Ejército (René Schneider) de perpetrar un golpe de Estado y al no lograrlo recurrió a sus aliados de la ultraizquierda que lo asesinaron tres días antes de que el Congreso pleno ratificara el triunfo de Allende.

Paros patronales, huelga de médicos, de camioneros que trasportaban productos de primera necesidad al interior del país, bloqueo de carreteras, atentados contra vías férreas, $y$ gaseoductos, entre otras formas de sabotaje se sucedieron en los mil días de gobierno popular.

Éramos testigos de cómo productores, distribuidores y comerciantes de derecha escondían los productos básicos: alimentos, medicinas, refacciones y una larga lista eran traficados mediante el mercado negro.

Como respuesta se crearon las juntas de abastecimientos y precios para proveer de esos productos, principalmente de alimentos, a precios justos a los consumidores, con la enorme dificultad que implicaba el hecho de que el Estado controlaba apenas el 25 por ciento de la producción de alimentos.

Los jóvenes de entonces participábamos activamente en distintos proyectos para revertir o paliar la embestida derechista. Como voluntarios de la UP colaborábamos en esas juntas y enfrentábamos los ataques -incluso físicos- de los opositores. El compromiso era mayor a cualquier dificultad, nada nos detendría, no claudicaríamos. Era la guerra entre David y Goliat.

- ¿Cómo se interrumpió ese proyecto con el golpe de Pinochet?

El 11 de septiembre de 1973 está grabado a fuego en mi memoria y en mi alma. Desde la azotea de mi lugar de trabajo - la editorial Qui- mantú- vi a los aviones de la Fuerza Aérea de Chile bombardear el Palacio de La Moneda icon el presidente constitucional adentro!

Ese fatídico 11 de septiembre significó un corte en mi historia y el comienzo de la noche más negra en mi país. Sueños interrumpidos, proyectos arrancados de cuajo, represión brutal. Miles de muertos, desaparecidos, torturados, encarcelados, exiliados.

Chile se convirtió mediante decretos en otro país: se clausuró el Congreso, se proscribieron los partidos políticos, se desconoció a los sindicatos, se anuló el derecho a huelga, se amordazó a la prensa libre. ¿Cómo entenderme en ese contexto? Fue un sisma del que no estoy segura haberme recuperado. Entonces sobrevino el exilio con prohibición de entrar a Chile.

Salir del país sin papeles, sin dinero... En mi caso, con mis cuatro hijos que no podían entender por qué. Y comenzar la vida en un lugar, yo sin trabajo y ellos sin abuelos, sin juguetes, sin amigos. Quien no lo haya vivido no podrá entender el dolor de no poder pararte bajo el árbol donde te dieron tu primer beso, ni visitar la tumba de tus padres, ni recorrer tus calles, ni hablar tu propio idioma $y$ tener que aprenderlo casi todo de nuevo.

Y esperar el día en que te permitan regresar. Y regresar a un país que fue tuyo y que te arrebataron y que sientes que ya no es. El retorno puede ser tan doloroso como la partida.

- ¿Ve usted algo de la up en el movimiento social tras el estallido de octubre de 2019 en Chile?

En 1980, 16 y medio años después de que la dictadura se instalara en Chile aboliendo la Constitución y promulgando otra redactada por sus secuaces, que permitió instaurar a rajatabla el modelo económico neoliberal, un plebiscito puso fin a $16 \mathrm{y}$ medio años del mandato de Pinochet $y$ dio paso a la llamada transición a la democracia. Se mantuvo, sin embargo, la vigencia de la Constitución de la dictadura. Comenzó entonces la etapa del gatopardismo "que todo cambie para que todo siga igual".

En octubre de 1919 comenzó en Chile un inédito estallido social, protagonizado por jóvenes $y$ al que se fueron uniendo diversos sectores 
de la sociedad para decir ¡basta!, inspirados por una pregunta fundamental ¿puede haber democracia en un país que se rige por la Constitución de un dictador? y cuya principal exigencia - por tanto - es un plebiscito para una nueva Constitución. El gobierno del derechista Sebastián Piñera ha respondido con represión brutal protagonizada principalmente por la policía militarizada (Carabineros).

Un soplo de esperanza recorrió otra vez Chile y cada vez más se fortalece la rebelión ciudadana a la que se suman diversos sectores de la sociedad. Los jóvenes - principales protagonistas del movimiento- rescatan muchas de las propuestas de la Unidad Popular reivindicando así el legado de Salvador Allende. 47 años no han sido suficientes para abolir la utopía. Lo dijo Salvador Allende en sus últimas palabras: ¡La historia es nuestra y la hacen los pueblos!

JAIME LORCA TOBAR

DIRECTOR CENTRO DE FORMACIÓN MEMORIA Y FUTURO

\section{- El día de la victoria}

Era la cuarta vez que Salvador Allende se postulaba a la Presidencia de la República, enfrentaba a la derecha y al centro dividido. La izquierda había logrado ensamblar una amplia coalición de fuerzas políticas cuyo eje eran socialistas y comunistas, los partidos de la clase trabajadora, pero que incorporaba también a vastos sectores cristianos, laicos e independientes de avanzada que reflejaban la adhesión de las clases medias urbanas a la Unidad Popular, la UP.

En ese histórico 4 de septiembre yo tenía 17 años y cursaba el tercero medio, el penúltimo año antes de egresar del prestigioso liceo el Instituto Nacional, y en el cual habían estudiado, amén de numerosos próceres, nuestro padre y mis tres hermanos. Allí, yo participaba en la organización de estudiantes socialistas los cuales, en alianza con otras organizaciones de izquierda, la Unidad Popular, controlaban el centro de alumnos, haciendo una activa vida de foros, debates especialmente previos al proceso electoral.

Esa campaña logró movilizar amplios sectores y estuvo impregnada de creatividad y espíritu unitario, creándose los CUP, los comités de unidad popular donde los chauvinismos partidarios tendían a atenuarse. Participé en numerosas acciones electorales en poblaciones populares yendo con otros jóvenes de la UP a difundir el programa y sus 40 medidas, $y$ lograr adherentes para la candidatura popular de Salvador Allende. Allí enfrentábamos a veces el sectarismo que se daba en la base, en la falta de capacidad para entender al que pensaba distinto $y$ la disposición de convencer con argumentos y respeto al que disentía, para engrosar las filas de quienes adherían a los cambios sociales. Nada más ajeno a lo que era la prédica y la práctica de Salvador Allende.

Yo pertenecía a una familia de clase media acomodada y era el menor de cuatro hermanos, todos socialistas. Nuestra madre adhirió a la candidatura reformista avanzada del democristiano Ramiro Tomic, quien había dicho, "sin Unidad Popular no habrá candidatura Tomic". Nuestro padre era partidario del candidato derechista Jorge Alessandri.

Ese histórico 4 de septiembre de 1970 , Salvador Allende obtuvo un estrecho triunfo sobre Alessandri y celebró la Victoria desde los balcones de la emblemática FECH, la Federación de Estudiantes de Chile, simbolizando el rol que la juventud había jugado en la campaña y que jugaría a lo largo del proceso revolucionario que en poco mas de 1000 días conmocionó al país, despertó simpatías en todo el mundo y también la odiosidad del imperio norteamericano.

Esa noche desde los balcones de la FECH en un improvisado pero contundente discurso, el compañero Presidente, como acostumbrábamos llamarle, nos habló con franqueza y claridad como acostumbraba hablarle al pueblo, nos llamó a disfrutar la alegría de la limpia victoria alcanzada pero al mismo tiempo nos advirtió del mañana duro que tendríamos por delante y la necesidad de poner mas pasión, más entrega para hacer más grande a Chile y más justa la vida en nuestra tierra. El 
ya avizoraba la resistencia de los adversarios del progreso social, de la feroz embestida del imperio que pocos días más tarde se reunía en Washington DC para en palabras de Nixon "hacer chillar la economía chilena", de allí la importancia de lo que se llamó la "batalla de la producción" y de la disciplina en torno al programa de las fuerzas revolucionarias. Esa noche y los días que le siguieron los vivimos intensamente $y$ fueron para los que participamos de ello tiempos inolvidables y magníficos, cuya trascendencia no fue opacada por la brutal dictadura que se descargó sobre el pueblo por la osadía de haber pretendido tomar el cielo por asalto $y$ haber buscado hacer más digna la vida en nuestra Patria.

\section{- 11 de septiembre de 1973}

Han transcurrido ya cincuenta años del golpe; sin embargo, los recuerdos de aquel aciago día, de sus días previos y posteriores, siguen presentes en mi memoria, a pesar de que muchos detalles tienden a atenuarse. Por ello, es apropiado que escriba estas líneas que me permite recordar mi historia que, en cierto modo, es muy similar a la historia de miles de jóvenes que adherimos con pasión al proyecto de la Unidad Popular (UP) y al liderazgo del Heroico Presidente Doctor Salvador Allende, cuyos sueños y esperanzas de un país mejor y más justo resultaron frustrados por largos años, por décadas. Afortunadamente, pese a los dolores, la gran mayoría de esa generación permaneció fiel a los ideales que les convocó en esos gloriosos Mil Días del Gobierno Popular.

Iniciaré mis recuerdos con estas elecciones claves, en las cuales la UP tuvo un contundente apoyo de casi el $44 \%$ de los votos válidamente emitidos. Esa inmensa votación de respaldo se obtuvo en medio de una severa crisis económica y de sus consecuencias sociales.

Esa crisis fríamente planeada por el gobierno de Nixon y Kissinger desde antes de la asunción de Allende, había sido muy bien implementada por las fuerzas reaccionarias locales, ya desde mediados de 1971. Estas las encabezaban el gran empresariado, los partidos de derecha, expresados en el Partido Nacional, y grupos fascistas agrupados en el autodenominado Frente Nacionalista Patria y Libertad que con el acaparamiento, la especulación, las acciones de masas y los atentados terroristas lograron desatar la crisis. Así fueron arrastrando a su estrategia de ingobernabilidad a amplios sectores de las llamadas capas medias, con sus organizaciones de pequeños y medianos empresarios, colegios profesionales, sectores de la juventud e incluso partes de la llamada aristocracia obrera.

La derecha pretendía obtener dos tercios del Parlamento por la vía de la acusación constitucional y así destituir al Presidente Allende. Al no resultar su pretensión, por el sólido respaldo a los partidos de la Unidad Popular, optaron por la vía golpista; no obstante, se toparon con un gran obstáculo: la presencia de militares constitucionalistas, encabezados por el Gral. Carlos Prats (Comandante en Jefe del Ejército) y un núcleo de generales leales con mando de tropa que le respaldan, en el Ejército $y$ en Carabineros.

Yo tenía 20 años y estudiaba economía en la Universidad de Chile, pero debo admitir que gran parte de mi tiempo lo dedicaba al trabajo político en la Juventud Socialista, la Js, específicamente en la Brigada de Estudiantes Secundarios Socialistas de Santiago, la cual tenía gran influencia dentro del movimiento estudiantil en liceos y escuelas públicas de la capital.

Desde esas elecciones de marzo de 1973, la dirigencia de la Js empezó a alertarnos respecto de la posibilidad de un golpe de estado, dada la opción estratégica adoptada por la derecha y el centrismo demócrata cristiano progresivamente derechizado. Esa posibilidad devino en certeza luego del sofocamiento por parte del General Prats, en ese entonces Comandante en Jefe del Ejército y de fuerzas constitucionalistas del ensayo golpista llamado el Tancazo, la sublevación del Regimiento Blindado $\mathrm{N}^{\circ} 2$ a fines de junio de 1973. Poco tiempo después los sectores golpistas del Ejército lograron provocar la renuncia del Gral. Prats y los oficiales constitucionalistas y remover con ello el último obstáculo para sus propósitos de revertir, ahogando en sangre, un proceso revolucionario que transcurría por cauces 
pacíficos e institucionales, con pleno respeto a los derechos y garantías individuales, tal y como lo había prometido el Presidente Allende.

- El proceso revolucionario de la UP y el proceso constituyente abierto por el estallido social

El proceso revolucionario que encabezó el Presidente Allende y su Gobierno de la Unidad Popular tuvo como preludio y componente esencial un gran protagonismo y movilización popular expresada en diversas formas de lucha, organización y constitución de gérmenes de poder popular.

En efecto antes del triunfo de septiembre la campaña estuvo signada por una campaña electoral masiva e innovadora que tuvo soporte en la creatividad de numerosos artistas que dieron vida al movimiento de la Nueva Canción Chilena, las brigadas muralistas y los artistas plásticos, la danza y las artes escénicas que promovieron la conciencia de amplias masas ciudadanas. El rol de la juventud, como principal aliada de los trabajadores del campo y la ciudad, en ese triunfo y en el desarrollo todo el proceso fue reconocido por Presidente Allende al celebrar la noche de la Victoria del 4 de septiembre desde los balcones de la Fecha Federación de Estudiantes de la Universidad de Chile.

También ha sido la juventud la vanguardia de las movilizaciones que estallaron un 18 de octubre del 2019 a propósito de una acumulación de injusticias y atropellos largamente incubadas no solo en los 17 años de atroz dictadura sino y lo que es muy paradójico, en los 30 años de la democracia de bajo impacto que le sucedieron, frustrando las esperanzas depositadas en ella. De allí que una de las consignas del movimiento fue "no son treinta pesos, son treinta años". El transporte subterráneo de Santiago, el Metro, había decidido alzar las tarifas en $\$ 30$ en su horario punta $y$ los estudiantes secundarios reaccionaron de inmediato en solidaridad con sus padres $y$ abuelos, ya que a ellos no les afectaba directamente, $y$ empezaron a evadir masivamente el pasaje saltando los torniquetes.

Esas manifestaciones fueron brutalmente reprimidas por la policía militarizada de Chile, los Carabineros, lo que no hizo más que inflamar la pradera reseca $y$ ese movimiento se masificó y el viernes 18 de octubre en la tarde ya no era solo de los estudiantes secundarios sino de amplios sectores populares $y$ ya no se limitaba a la capital sino que se extendía a lo largo del país; en los días siguientes el movimiento se politizo articulando diversas reivindicaciones largamente anheladas como las movilizaciones de la juventud por educación pública gratuita $y$ de calidad, de fin a las AFP, de la administradoras de fondos previsionales que están entregando jubilaciones de hambre obligando crecientemente al gobierno a tener que complementarlas, contra el hambre, la falta de empleos y oportunidades por el fin de la brutal represión ya que el disparo de balines a los ojos dejaron a cientos de manifestantes lisados perdiendo su vista, total o parcialmente, a ello se sumó el movimiento feminista con originales manifestaciones de protesta contra el machismo que dieron vuelta al mundo.

Este movimiento masivo fue impulsando también la aspiración de una nueva constitución genuinamente democrática surgida en democracia y generada mediante Asamblea Constituyente. El movimiento fue espontáneo, surgido al margen de los partidos políticos y también de las organizaciones sociales. El sector más dinámico fueron jóvenes populares de barrios marginales, periféricos que, desempleados, o subempleados o cuentapropistas, que sobreviven a duras penas, que el sistema neoliberal le ha dejado al margen, sin darles cabida, muchos de ellos no estudian ni trabajan y provienen de hogares mal avenidos cuando existe tal concepto, que se han criado solos o con sus grupos de afinidad, desde barras bravas a grupos deportivos, e incluso en torno a los narcos. Muchos alejados de las juventudes políticas y de las organizaciones religiosas, especialmente la católica, otrora muy influyentes en la juventud popular.

El 12 de noviembre en Santiago se reunieron 1,2 millones de personas en una inmensa manifestación combativa pero básicamente pacífica, cuyo epicentro durante los casi 5 meses en que se extendieron las protestas en Santiago fue la ex Plaza Italia o ex Plaza Baquedano, hoy denominada Plaza de la Dignidad. 
Esas manifestaciones se replicaron en la totalidad de las ciudades y muchísimos pueblos de Chile. Allí la llamada "clase política" comprendió que era urgente buscarle una salida institucional a un conflicto político que amenazaba escalar hasta hacer ingobernable al país o tener que acrecentar la brutal represión militarizando al país y entonces llegó a una Acuerdo por la Paz y la nueva Constitución abriendo paso al proceso constituyente que se iniciara el próximo 25 de octubre en el plebiscito de entrada para decidir si se quiere o no una Nueva Constitución y mediante que mecanismo: Convención Constitucional, $100 \%$ electa, o Convención Mixta, conformada paritariamente por parlamentarios y representantes electos.

Chile enfrentará una decisión crucial, histórica, que no hubo posibilidades en estos largos treinta años de transición, cuál es la posibilidad de poner fin a la Constitución de Pinochet impuesta en dictadura y que pese a todas la reformas y remiendos sigue siendo, en esencia, la Constitución de Pinochet aquella que sustenta el sistema neoliberal de ultra capitalismo que favorece los intereses de la oligarquía cada vez mas distante y contrapuesta al interés nacional.

Al igual que en el proceso revolucionario de la Unidad Popular, para que la actual ventana de oportunidad abierta por las movilizaciones del 18/0 fructifique, los trabajadores, únicos capaces de ofrecer un orden alternativo al burgués, deberán ponerse al frente de este proceso constitucional y los partidos políticos populares deberán procurar a través de políticas claras y consecuentes recuperar el prestigio en gran medida perdido, y ser capaces de construir una plataforma programática de cambios y práctica unitaria como lo fueron capaces en épocas de la Unidad Popular.

\section{CARLOS HUMBERTO CASZELY \\ JUGADOR DE FÚTBOL \\ SELECCIONADO NACIONAL EN 1971}

- ¿Qué significó para ¿usted el ascenso de Allende a la Moneda el 4 de septiembre de 1970?
Tenía como dieciocho años, estaba en la Universidad cuando se empieza a dilucidar quién podría ser el Presidente de Chile y recuerdo que decían: "Cuando seamos dueños del cobre, no los americanos, iChile va a tirar para arriba!". Imagínate, con dieciocho años, en esa época éramos inocentones. En el barrio, en la Universidad, todos decían: "si Allende es elegido Presidente, el cobre va hacer nuestro".

Nunca me voy a olvidar lo que me dijo una vez mi mamá: "Tú eres dueño de la casa, la arriendas y esa gente le pone los muebles. Después te la quieren vender. ¡no, poh, eso es lo mismo que el cobre. El cobre es nuestro, ellos ponen las máquinas y te lo venden más caro. No poh, no puede ser. Entonces al ser de nosotros, nosotros vamos a cobrar por el cobre, por el oro, por el platino y vamos a tener más plata para la educación, imás plata para todos y vamos a ser un país mas grande!". Ese es el recuerdo que yo tengo de Salvador Allende, yo estuve con él tres veces $y$ me hice amigo de él y comprobé que tenía bastantes coincidencias con él. Eso era lo que él pretendía. Con el tiempo, aún jóvenes, cuando uno empieza a leer, cuando se empiezan a desclasificar los documentos de Estados Unidos, uno se da cuenta que tanto la Democracia Cristiana como la derecha en Chile, empezaron a hacer la cama, sí, a hacer la cama para que terminase todo eso. Y uno nunca quería que eso terminara en un golpe de Estado.

Cuando estaba en el centro deportivo Pinto Durán, "El Zorro" Álamos nos dijo "¡Hay un golpe de Estado!". Y los muchachos dicen "¿Qué es eso, de qué se trata?". En esa época, para nosotros, un golpe de Estado era impresentable.

\section{- ¿Cómo vivió el fin abrupto de esa "revolución" con el golpe de estado de 11.09.73?}

Fue impresentable entonces, y a los treinta años, $y$ a los cuarenta $y$ siete años del golpe, sigue siendo impresentable. Para mí no solo es impresentable una dictadura, sino también las guerras. No puedo comprender por qué la gente no se entiende dónde está la maldad de quienes gobiernan. Me parece que está en la propia mente del ser humano. De allí fluyen todas las ansias de poder, las ansias 
del dinero... esas ansias de tener más y más itanto! acumular, acumular, pero para qué, si el último viaje no tiene bolsillo. Fue un duro golpe para mi porque nunca he ocultado mis ideas progresistas y mi apoyo al lado del gobierno de Unidad Popular.

- Cuando quizá ya no soñábamos más con revoluciones, vino en Chile el estallido social del año pasado. ¿Hay algo del espíritu de la UP en este nuevo proceso que pretende terminar con las inequidades del modelo impuesto por la dictadura?

El estallido social lo veo desde la cuneta. Es decir, desde afuera, mirando $y$ analizando todo lo que pasa. Te voy a ser muy sincero, me equivoque o no. Yo tengo un pensamiento diferente a todo lo que está pasando ahora. No puedo renunciar a mis principios.

Cuando la derecha traicionera de este país caga a Allende, uno decía, ipero ¡cómo quieren destituir a Salvador Allende, si fue elegido democráticamente! No me gusta Piñera, pero estoy en contra de que lo saquen de la Presidencia de la República. Él fue elegido democráticamente con el $56 \%$ de los votos depositados en las urnas, con una altísima abstención. Pero el juego democrático es así. Y aunque hoy tenga solamente el $6 \%$ de aprobación, nunca antes visto en nuestra historia, él fue elegido democráticamente.

Hay quienes dicen "ique se vayan los ricos!" yo digo, si se van, van a venir otros nuevos ricos. A mí me preocupan los pobres. En el año 80, fui de los pocos huevones que dijimos no a la Constitución. Allende logró el 3\% del cobre y metió a Estados Unidos detrás. El agua y la luz deben ser estatales, porque son un bien básico. Los que saben dicen que, si tú le quitas un $25 \%$ al cobre, $y$ le agregamos el 25\% del litio, lograríamos tener una mejor educación y una mejor salud pública. Por todas estas cosas es por lo que estoy sentado viendo como pasa todo este proceso.

Cuando hay un millón $y$ medio de personas reclamando por nuestra dignidad, lo encuentro estupendo. Creo que ya no podríamos parar a este monstruo pequeño, pero muy violento que nos han metido. Nosotros queremos la paz, con grandes cambios, sin duda.
Cuando el 18 de noviembre llegan a un acuerdo todos los partidos políticos a un acuerdo nacional imentira! Porque son los mismos que han estado 30 años profitando. Fíjate que, cuando Piñera acusó a los "cómplices pasivos", pienso que hoy todos son cómplices pasivos. Hace unos días escuché que todos tienen cagadas detrás. Yo quiero la Asamblea Constituyente, pero con otras personas. ¿Cómo no va a haber 50 gallos capos en derecho constitucional, más allá de estos políticos?

Tenemos que encontrar a esos expertos, a esas personas que sí sean bastante honorables, que no tengan coimas, que no hayan sido comprados por las grandes empresas. Considero, que los actuales políticos son cómplices pasivos de lo que está pasando. Entonces, quiero la Asamblea Constituyente, pero sin ninguno de estos huevones ininguno! Este es un gran proceso, es un proceso largo, para unos años más. Hay que tener claro que mañana no van a cambiar las Isapres.

¿Por qué fue el estallido social? Porque quedó en evidencia que este sistema es injusto, que ha agrandado las diferencias, las inequidades, los abusos, la corrupción. Y quedó en evidencia, porque los ministros se mandaron puras cagadas. Dijeron "estamos en guerra", pero la gente no tiene armas para ese tipo de guerras. Y el otro dijo, "levántense más temprano para hacer vida social", con un descriterio que sonó a burla inadmisible. Y en el marco de la pandemia por el corona virus, va otro $y$ dice "esto no prendió, tenemos la mejor medicina del mundo". Y, para colmo de males, el propio Presidente va a hacerse una foto junto al monumento de Baquedano, en la Plaza de la Dignidad, lo que constituye otra provocación inadmisible.

\section{VICENT GARCÉS}

INGENIERO AGRÓNOMO

COLABORADOR DEL GOBIERNO DEL

PRESIDENTE ALLENDE

EXDIPUTADO DEL PARLAMENTO EUROPEO.

- ¿Qué significó para Vd. el ascenso de Allende a la Moncloa el 4 de septiembre de 1970? ¿Cómo vivió el inicio del proyecto de la Unidad Popular en Chile? 
Los años 1970 y 1971 yo estaba moviéndome en Francia. Había terminado mis estudios de Ingeniero Agrónomo en España y realice una especialización en Planificación y Desarrollo Rural en el Institut Agronomique Méditerranéen (IAM) de Montpellier y me dirigía hacia el Doctorado en el Institut National Agronomique de París.

En el IAM de Montpellier coincidí con un grupo de Ingenieros Agrónomos chilenos que realizaban los mismos estudios que yo, y pronto simpatizamos y convergimos en el interés por el proceso que se estaba desarrollando en su país: la vía chilena al socialismo, en libertad $y$ democracia.

Yo venía de la España sometida a la dictadura del General Franco, de participar en los movimientos estudiantiles contra ella y por la democracia, $y$ estaba viviendo el post Mayo del 68 en Francia. En ese contexto, el interés político que suscitó la victoria de Allende fue inmenso. Más si cabe, porque mantenía comunicación fluida con mi hermano Joan Enric que se encontraba en Santiago de Chile como asesor político del candidato a la presidencia $y$, posteriormente, presidente Salvador Allende.

Además, en el INA de París, en contacto con los profesores René Dumont y Marcel Mazoyer, yo había planteado hacer mi tesis doctoral sobre un estudio comparado de las reformas agrarias en España durante la II República y la desarrollada en Chile durante la Unidad Popular.

Todas estas circunstancias me llevaron a trasladarme a vivir y trabajar en Chile, donde colaboré estrechamente hasta el 11 de septiembre de 1973 en la Oficina de Estudios y Políticas Agrarias (ODEPA), con el Ministro de Agricultura Jacques Chonchol y el director de la Oficina Jorge Echenique.

El inicio del Gobierno del presidente Allende se vivió en toda Europa, y más aún en España, como una conquista histórica: por primera vez, por la vía electoral, en condiciones de libertad y democracia, llegaba al Gobierno un presidente, una coalición y un Programa que planteaba cambios revolucionarios en un país del tercer mundo como era Chile. Las expectativas levantadas y las esperanzas de transformación y cambio fueron enormes.

Muy rápidamente se visualizó la potente oposición de los poderosos y del Gobierno de los
EE.UU. a las aspiraciones del Gobierno de Chile de poner la economía y los sectores productivos al servicio del pueblo. El asesinato del Comandante en Jefe René Schneider, los bloqueos desde el exterior, la huelga de camioneros y tantos otros acontecimientos similares hicieron que la solidaridad de las capas populares del mundo con el proceso chileno se expresará de mil maneras.

En mi caso y sobre el terreno seguí muy de cerca el proceso de reconocimiento de derechos al campesinado chileno, empezando por el derecho a la tierra, los intentos de racionalizar y aumentar la producción de alimentos para la población, los boicots tanto a la producción como a la distribución de alimentos, la mejora de la educación y la sanidad en los ámbitos rurales y tantas otras cosas que hicieron del proceso chileno un proceso único.

- ¿Qué significó el fin abrupto de esa

"revolución" con el golpe de estado del 11-09-1973?

No fue un fin abrupto, fue un golpe militar organizado $y$ ejecutado por fuerzas civiles $y$ armadas, coordinadas desde dentro y fuera del país, con el único fin de acabar con un proceso político y social democrático que no habían podido vencer electoralmente. El 11 de septiembre de 1973 se verificó, una vez más en la historia, que las derechas del sistema, opulentas y privilegiadas, no creen en la democracia, solo la usan cuando la controlan. Mis sensaciones, a medida que avanzaban las horas aquel 11 de septiembre eran de una gran frustración e impotencia al ver como se imponía por la fuerza de las armas lo que no se tenía por la fuerza de la razón.

El presidente Allende, desde el palacio presidencial de La Moneda, acababa de denunciar por radio a los autores del crimen contra la humanidad que se estaba perpetrando: "Soldados de Chile, comandantes en jefe titulares, el almirante Merino, que se ha autodesignado, más el señor Mendoza, general rastrero que sólo ayer manifestara su fidelidad y lealtad al Gobierno, también se ha autodenominado Director General de Carabineros ....."

El capital foráneo, el imperialismo, unido a la reacción, creó el clima para que las Fuerzas Armadas rompieran su tradición, la que les enseñara el Schneider y reafirmara el comandante Araya, víctimas del mismo sector social que hoy 
estará en sus casas esperando con mano ajena, reconquistar el poder para seguir defendiendo sus granjerías y sus privilegios"... ..."En nuestro país el fascismo ya estuvo hace muchas horas presente; en los atentados terroristas, volando los puentes, cortando las líneas férreas, destruyendo lo oleoductos y los gaseoductos, frente al silencio de quienes tenían la obligación de proceder".

Esas palabras atronaban en mi mente de joven español antifranquista, antifascista y demócrata aquella mañana. Narraban lo que, salvando las distancias de tiempo y espacio, había pasado en España con el golpe militar fascista del 18 de julio de 1936 contra la II República. Estaba viviendo, en vivo y en directo, la técnica militar del golpe de estado contra un gobierno legítimo y democrático. Estaba en el inicio de una larga noche dictatorial contra los sectores del pueblo que habían apoyado con su voto, sus ilusiones, sus esperanzas y su trabajo al Gobierno del presidente Allende y de la Unidad Popular. Estaba viendo como la potencia hegemónica en el continente se imponía nuevamente por la fuerza, por la violencia, por la muerte y la represión.

El golpista General Pinochet resultó un aprendiz del golpista General Franco. Los intereses económicos y sociales que defendían eren los mismos: los de los poderosos, los de las clases dominantes, privilegiadas, que no creen en la democracia y que usan la violencia contra las instituciones públicas cuando democráticamente no pueden seguir controlando el poder. Una cosa si habían aprendido los golpistas chilenos: antes de enviar las tropas a la calle había que controlar la totalidad de la cúpula militar y los circuitos del mando. Y lo hicieron, tal como lo describe en sus últimas palabras Salvador Allende. Dieron un golpe en el seno de las FF.AA. $y$ con la verticalidad del mando asegurada, lanzaron las tropas contra el Gobierno democrático y los sectores populares de apoyo. La historia no los ha absuelto ni los absolverá.

- Cuando quizá ya no soñábamos más con revoluciones vino en Chile el estallido social del año pasado. ¿Hay algo del espíritu de la UP en este nuevo proceso que pretende terminar con el modelo impuesto por la dictadura?

En el mundo todavía se sueña con la justicia, con la igualdad, con la libertad y con la solidaridad. Son valores universales que trascienden las generaciones y los tiempos. La humanidad nunca dejará de soñar y tratar de alcanzarlos.

En el mundo globalizado de hoy día, después de cuatro décadas de aplicación de las políticas neoliberales, con una gran concentración del poder y de la riqueza, con desigualdades crecientes, la ciudadanía, los pueblos de los cinco continentes siguen soñando y luchando por un mundo distinto $y$ mejor. En Chile la revuelta ciudadana del año pasado es un gran indicador de que los sueños no han muerto.

Es curioso observar como la demanda actual de un proceso constituyente para acabar definitivamente con la Constitución proclamada por el criminal General Pinochet el año 1980, se asemeja a la demanda de un proceso para una nueva Constitución, que quería anunciar el presidente Allende el día 11 de septiembre de 1973.

Los golpistas abortaron el proceso político, democrático, que visualizaba Allende para superar la crisis de aquellos momentos. Esperemos que, en esta ocasión, el pueblo de Chile encuentre los caminos para seguir avanzando y superar las trampas de todo tipo que se le van a tender.

Esos caminos tienen mucho que ver con las ilusiones, las esperanzas y las propuestas del Programa de la Unidad Popular, que el presidente Allende encarnó y defendió hasta su muerte. Lo que nunca entendieron los golpistas, y nunca entenderán sus sucesores, es que en la memoria y en las esperanzas del pueblo de Chile $y$ de los pueblos del mundo Allende y su pensamiento siguen vivos.

\section{EULOGIO DÁVALOS \\ GUITARRISTA \\ PARTICIPÓ EN EL SELLO DICAP (DISCOTECA DEL CANTAR POPULAR) \\ EXILIADO EN BARCELONA DESDE 1974}

- ¿Qué significó para ¿usted el ascenso de Allende a la Moneda el 4 deseptiembre de 1970?

Lo revivo todos los días, y lo reviví hace poco, cuando volví a votar después de la última vez que lo hice en Chile el 4 de septiembre de 
1970. Participé activamente en la concreción de ese sueño que tenía Salvador Allende, en particular me involucré en la materialización de la política cultural de la UP, expresada en la Medida 40, que tenía por objetivo final la realización de los Institutos provinciales de cultura en cada rincón del país. Participé en la Discoteca de la Canción La Discoteca del Cantar Popular (DICAP) que fue un sello discográfico chileno surgido entre 1967 y 1973 perteneciente a las Juventudes Comunistas de Chile para publicar a los artistas que no tenían espacio en los sellos multinacionales por sus temáticas contestatarias y anticapitalistas, convirtiéndose en el soporte discográfico de la Nueva Canción Chilena.

Y luego, por su puesto en el Tren Popular de la Cultura. Entre el 15 de enero y el 16 de febrero de 1971, participó en el Tren Popular de la Cultura, recorriendo innumerables pueblos y ciudades, una experiencia que fue la más rica de mi vida, en cuanto a la vivencia $y$ aprendizaje personal de la sensibilidad de miles niños, trabajadores y gente humilde de su país. El proyecto era dependiente de la secretaría general de gobierno de la uP y en él participaron, entre otros, escritores como Armando Casígolli y Edmundo Herrera; actores como María Eugenia Cavieres, Peggy Cordero, Luis Alarcón, Adriano Castillo y Sergio Buschman y un elenco artístico musical que incluía a Rolando Alarcón, el grupo "Rauquén", Osvaldo Madera, Los Emigrantes y Nano Acevedo.

Todo el programa de la Unidad Popular, sus objetivos, su implantación, sus luchas y la resistencia que después se impuso, porque permitía la realización del hombre nuevo en todas sus facetas, refleja el espíritu de trabajo, la capacidad creadora y el esfuerzo del pueblo de Chile, representado por: sus obreros, sus técnicos, sus artistas, sus profesionales.

- ¿Cómo vivió el fin abrupto de esa "revolución" con el golpe de estado de 11.09.73?

Comenzaron temprano las marchas militares en la radio, pero, aun así, me dije que tenía que ir a mi trabajo en la universidad. Pero no había buses y el centro de Santiago ya estaba cortado. Regresé a casa a tiempo de escuchar las últimas palabras de Allende. De ese día me queda en la memoria y fuerte la última frase de su discurso: «De nuevo se abrirán las grandes alamedas por donde pase el hombre libre, para construir una sociedad mejor».

La compostura de Allende fue tremenda: dijo que solo lo sacarían muerto del Palacio de La Moneda. Los acontecimientos lo empujaron a quitarse la vida. Pero Allende murió para vivir; su muerte fue la condena más grande que tuvo, ya desde el principio, la junta militar.

Para mí, el camino del exilio se inició algunos años después. Llegué a Barcelona el 15 de enero de 1975. Tuve que salir porque una amiga, "jugándose el pellejo", me avisó de que tenía tres acusaciones sumarias por haberme reunido con personas comprometidas.

Los españoles estaban en la dictadura franquista, $y$ en cuanto llegábamos los latinoamericanos, nos colocaban un sello en el pasaporte: «No autorizado para trabajar en España». Había que salir a Perpiñán cada tanto para volver a entrar como turista. No fue fácil.

- Cuando quizá ya no soñábamos más con revoluciones, vino en Chile el estallido social del año pasado. ¿Hay algo del espíritu de la UP en este nuevo proceso que pretende terminar con las inequidades del modelo impuesto por la dictadura?

El estallido social llegó en un momento en que yo había ya pensado que los chilenos se habían adaptado a las incongruencias del modelo liberal. Para mí fue una sorpresa que Chile despertara y que lo siga haciendo esta vez apoyando la transformación de la Constitución de Pinochet que tanto asfixia a los chilenos. Sí, tiene algo de la UP en el sentido de que hay un espíritu de cuerpo por conseguir cambios en Chile. Espero que siga evolucionando. 